\title{
Recenzje
}

Janis Augsburger, Masochismen. Mythologisierung als Krisen-Ästhetik bei Bruno Schulz, Wehrhahn Verlag, Hannover 2008, ss. 344.

\section{Masochizm i estetyka. \\ O nowych kulturowo-psychoanalitycznych interpretacjach twórczości Brunona Schulza}

Recepcja czytelnicza i naukowa twórczości Brunona Schulza ma swoją historię nie tylko w Polsce, ale i za granicą. Można w niej zaobserwować dwie wyraźne tendencje.

Po pierwsze, żaden chyba polski autor nie był odbierany, czytany i analizowany w sposób tak różnorodny jak twórca Sklepów cynamonowych. Odbiór ten biegnie niejako dwutorowo. Obok badań stricte literaturoznawczych - rozpatrujących dzieło Schulza w kontekście prądów literackich i filozoficznych XX w. - istnieją liczne świadectwa recepcji twórczej, inspirowanej nie tylko wątkami znanymi z opowiadań i grafik, ale też samym życiorysem pisarza (co jest zrozumiałe wobec autobiograficznego charakteru jego tekstów). Należą tu ilustracje, filmy, inscenizacje teatralne, a także oryginalna twórczość pisarska - powieści osnute na kanwie wydarzeń z życia Schulza ${ }^{1}$. W odbiorze czytelniczym spuścizna literacka i plastyczna autora Wiosny oraz jego biografia splatają się w jeden tekst kultury, będący punktem wyjścia różnorodnych intertekstualnych nawiązań.

Niezmiernie żywa jest przy tym recepcja dzieł Schulza i „schulzoidów” w kręgu niemieckojęzycznym. Prawie wszystkie powieści „schulzowskie” przełożono na język niemiecki dużo wcześniej niż na polski. Zainteresowanie postacia drohobyckiego nauczyciela przybiera formę filmów fabularnych i dokumentalnych, a także działań z pogranicza

1 Chodzi o powieści: Cynthii Ozick The Messiah of Stockholm (1987; wyd. polskie: Mesjasz ze Sztokholmu, Poznań 1994), Dawida Grosmana 'Ayen' Erekh: Ahavà (1986; wyd. polskie: Patrz pod: Miłość, Warszawa 2008), Ugo Riccarelliego Un uomo che forse si chiamava Schulz (1998; wyd. niemieckie: Ein Mann, der vielleicht Schulz hieß, München 2001) czy też Marca Ercolaniego Il mese dopo l'ultimo. Frammenti di un romanzo incompiuto (1999). O powieściach Ozick i Grosmana pisze Aleksander Fiut, Pośmiertne przygody Brunona Schulza, [w:] tegoż, Spotkania z Innym, Kraków 2006, s. 112-137. Najpełniejszy wykaz różnorakich artystycznych nawiązań do Schulza zawiera strona internetowa przygotowana przez Branislavę Stojanović: <http://www.brunoschulz.org> [dostęp 15 lipca 2011]. 
sztuk (niezwykły komiks Dietera Jüdta²). Twórcy tych świadectw często ignorują zdobycze oficjalnej, naukowej „schulzologii” - zarówno ustalenia biografów, jak i literaturoznawców. Zdają się raczej na własną fantazję i intuicję, przekazując indywidualny, emocjonalny i subiektywny obraz Schulza jako człowieka, bohatera literackiego i twórcy konkretnych tekstów ${ }^{3}$.

Po drugie, w ostatnich latach twórczość autora Wiosny stała się przedmiotem zainteresowania nie tylko badaczy literatury, ale także kulturoznawców oraz historyków sztuki ${ }^{4}$. W konsekwencji tzw. zwrotu kulturowego $\mathrm{w}$ humanistyce pojawiają się postulaty, aby pisarstwo Schulza uczynić przedmiotem badań interkulturowych ${ }^{5}$. Zapowiedzią nowych tendencji interpretacyjnych są nieliczne na razie propozycje, wpisujące autora Sklepów cynamonowych np. w dyskurs postkolonialny ${ }^{6}$. Zainteresowanie osobowością Schulza i jej przejawami artystycznymi wpisuje się w nowy paradygmat nauki o literaturze - dyscypliny, dla której szczególnie interesującym przedmiotem badań są postacie, zjawiska, przestrzenie, teksty o charakterze hybrydycznym, usytuowane na pograniczu kulturowym, literackim czy etnicznym. Bruno Schulz ze swą niejednoznaczną, wymykającą się prostym klasyfikacjom przynależnością narodową i etniczną, społeczną, religijną, językową - to modelowy wręcz przypadek „kulturowej hybrydy”.

Wspólną cechą najnowszych obserwacji i odczytań jest próba całościowego spojrzenia na dorobek autora Wiosny - zarówno literacki, jak i plastyczny, co wiąże się z dowartościowaniem tego ostatniego. Do tej pory ranga artystyczna grafik i rysunków drohobyckiego pisarza oceniana była różnie, przeważał jednak pogląd, że to w literaturze Schulz wypowiedział się najpełniej7. Rysunki interpretowano na ogół dość pobieżnie, w kontekście biograficznym lub jako dopełnienie tekstów literackich, a uwagi na ich temat miały zwykle charakter marginesowy.

2 D. Jüdt, Heimsuchung und andere Erzählungen von Bruno Schulz, Stuttgart 1995.

3 Tak postępuje np. D. Jüdt, wplatając w swój komiks - intersemiotyczną transpozycję Sklepów cynamonowych - graficzne motywy dalekowschodnie, dla których trudno szukać uzasadnienia w tekstach samego Schulza. Z kolei powieści Ozick i Grosmana można określić mianem fantastycznych wariacji osnutych wokół autentycznych wydarzeń $\mathrm{z}$ życia pisarza.

${ }^{4}$ Obecny stan badań najpełniej dokumentuje Stownik schulzowski pod redakcją W. Boleckiego, J. Jarzębskiego i S. Rośka, Gdańsk 2006.

5 Zob. A. Fiut, Pośmiertne przygody Brunona Schulza, dz. cyt., s. 135-136.

${ }_{6}^{6}$ Zob. D. Wojda, Schulzowskie reprezentacje pogranicza kulturowego $w$ perspektywie postkolonialnej, „Teksty Drugie” 2007, nr 4, s. 233-247.

7 Zgodnie zresztą z jego własnym odczuciem - zob. S. Wysłouch, Literatura a sztuki wizualne, Warszawa 1994, s. 129. 
Obecnie podejście to zaczyna się zmieniać - po trosze dzięki temu, że młode pokolenie „schulzologów” rekrutuje się już nie tylko spośród historyków czy teoretyków literatury. Wyrazem nowej tendencji są prace, w których analiza grafik Schulza stanowi integralną część wywodu literaturoznawczego ${ }^{8}$. Tak właśnie skonstruowana jest monografia Janis Augsburger - absolwentki filozofii i kulturoznawstwa berlińskiego Uniwersytetu Humboldtów, do niedawna wykładowczyni w tamtejszym Instytucie Kulturoznawstwa. Co znamienne, książka ukazała się w serii kulturoznawczej (Tromsøer Studien zur Kulturwissenschaft) wydawnictwa naukowego Wehrhahn z Hanoweru. Kulturoznawczo-filozoficzna proweniencja autorki uzasadnia jej spojrzenie na twórczość i biografię Schulza oraz na jej tło historyczne.

Choć Augsburger nie jest filologiem, podziw budzi jej literacka wrażliwość idąca $\mathrm{w}$ parze $\mathrm{z}$ rzetelnym podejściem do warstwy językowej omawianych utworów. Autorka, dobrze znająca język polski, opiera się na tekstach oryginalnych, zdając sobie sprawę $\mathrm{z}$ niedoskonałości istniejących tłumaczeń. Choć interesujące ją fragmenty prozy przytacza w niemieckim przekładzie ${ }^{9}$, to niekiedy proponuje własną, alternatywną wersję, oddającą sens Schulzowskich oryginałów w sposób bardziej adekwatny.

Książka Augsburger nie jest typową monografią. To raczej ciąg ściśle ze sobą splecionych, niezwykle erudycyjnych analiz, polemik oraz dyskusji z dawniejszym i obecnym stanem badań nad twórczością autora Wiosny. Luźna, dygresyjna struktura książki, w której trudno - mimo formalnego podziału - wyodrębnić samodzielne całości, a także brak tradycyjnego podsumowania czy też wniosków końcowych, mogą powodować pewien niedosyt i dezorientację. Rezygnację z zakończenia Augsburger uzasadnia faktem, że samo dzieło Schulza jest „otwarte”, oporne na wszelkie próby ostatecznego podsumowania ${ }^{10}$. Przyznaje się też do dylematu metodologicznego, jakim jest trudność w pogodzeniu strukturalistycznej koncepcji pracy z jej przedmiotem: tekstami, w których inkoherencja i przypadek odgrywają niebagatelną rolę (A 14). Autorkę motywuje zrozumiała ambicja i wewnętrzna potrzeba dostosowania toku argumentacji do kształtu artystycznego omawianych tekstów, co nie zawsze przekłada się na czytelność i przejrzystość wywodu. Niezależnie

${ }^{8}$ Przykładem takiej rozprawy polskojęzycznej jest studium D.K. Sikorskiego Symboliczny świat Brunona Schulza, Słupsk 2004.

9 Augsburger korzysta z przekładu Josefa Hahna, do niedawna jedynego; dopiero w roku 2008 ukazało się nowe tłumaczenie Sklepów cynamonowych pióra Doreen Daume, którego badaczka z Berlina nie mogła jeszcze uwzględnić.

10 Odniesienia do pracy Augsburger oznaczono w tekście głównym jako „A” z podanym numerem strony - tu: A 234. Tłumaczenia cytatów z recenzowanej pracy moje - K.L.

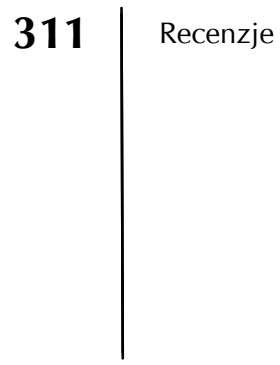


od tego mankamentu, w książce wyczuwa się osobisty, emocjonalny stosunek autorki do dzieł Schulza - charakterystyczny raczej dla twórców pozanaukowych, artystycznych świadectw odbioru.

Niemiecka badaczka stara się - inaczej niż jej poprzednicy - znaleźć taki wspólny mianownik dla opowiadań i grafik autora z Drohobycza, który wykraczałby poza biografizm i symbolizm. Zakłada, że Schulzowskie słowo i obraz tworzą nierozerwalną całość, której sens objawia się $\mathrm{w}$ kontekście indywidualnego losu pisarza oraz recypowanych przezeń prądów umysłowych, estetyki i filozofii kultury przełomu wieków i czasów międzywojennych. Klucza do całościowego odczytania spuścizny Schulza wraz z jej uwarunkowaniami historycznymi autorka z Berlina upatruje w splocie masochizmu i mitu. Celem książki jest unaocznienie ścisłego związku między obydwoma motywami u twórcy Sklepów cynamonowych i wykazanie, w jaki sposób masochizm ulega przekształceniu w retorykę mitologizacji (A 12).

Rzecz jasna pojęcie mitu od dawna towarzyszy rozważaniom nad tekstami drohobyckiego pisarza. O ile rozumienie mitu i mityzacji nie odbiega u Augsburger od dotychczasowych ustaleń, o tyle deklarowane przez nią ujęcie masochizmu ma charakter całkowicie nowatorski. Chodziłoby tu bowiem nie tylko o erotyczną perwersję, ale też o uniwersalną historyczno-kulturoznawczo-estetyczną kategorię interpretacyjną, udowadniającą nierozerwalną jedność wszystkich tekstów autora Xięgi bałwochwalczej. Augsburger nawiązuje do znanej koncepcji Artura Sandauera, który w prywatnym masochizmie Schulza widział sublimację historycznego doświadczenia społecznej i etnicznej degradacji w przeżycie estetyczne ${ }^{11}$, jednak w swojej definicji berlińska kulturoznawczyni chce iść znacznie dalej. Masochizm realizowany w sztuce byłby swoistą terapią historycznych i osobistych konfliktów, rozłamów i traum, poszukiwaniem ukojenia, wyrażanym zarówno na płaszczyźnie fizycznej (antagonizm płci), jak i duchowej - transcendentnej. Masochizm to zjawisko psychologiczno-socjologiczne, które mogło się wykształcić w pewnych warunkach dziejowych i w konkretnej przestrzeni geograficznej: w monarchii austro-węgierskiej XIX w. Fenomen ten jest obecny - w sposób mniej lub bardziej jawny - w sztuce powstałej w tym kręgu kulturowym, której Schulz jest wyrazistym, lecz nie odosobnionym przykładem.

Zapowiedź potraktowania masochizmu w kategoriach jednocześnie psychologicznych i historyczno-społecznych jest odważna, ale i ryzykowna. Autorka podejmuje bowiem pewne zobowiązanie interpretacyjne i metodologiczne, którego - jak się okazuje - nie zawsze jest w stanie dotrzymać.

11 Zob. A. Sandauer, Rzeczywistość zdegradowana. Rzecz o Brunonie Schulzu, [w:] B. Schulz, Sklepy cynamonowe. Sanatorium pod Klepsydra, Kraków 1957. 
W obrazach i tekstach nauczyciela z Drohobycza badaczka dostrzega zespół cech określany przez nią jako masochistyczna estetyka (co chyba należałoby ująć w cudzysłów, bo jest to termin nieco na wyrost). Zasadza się on na dwóch sprzecznych tendencjach, stojących wobec siebie w stosunku dialektycznym. Pierwsza $\mathrm{z}$ nich to dążenie do autodestrukcji, rozpadu (w znaczeniu fizycznym i duchowym), fragmentaryzacji sensu i groteskowej deformacji rzeczywistości, rozmycia granic własnego Ja i unieważnienia principium individuationis - rysy charakteryzujące masochizm jako dyspozycję psychiczną. Z drugiej strony w dziele pisarza uwidacznia się - również masochistyczna - tęsknota do integralności, przywrócenia pierwotnego ładu i sensu, zbawczej, symbiotycznej jedności z kobietą-matką (w wymiarze psychicznym) i Absolutem (na płaszczyźnie duchowej). Napięcie między tymi dwiema tendencjami - „formalna struktura rozpięta między cierpieniem a nadzieją zbawienia" (A 258) - to właśnie masochizm sensu largo, przybierający u Schulza postać mitu i powrotu do dzieciństwa. Jego tekstowe i wizualne realizacje Augsburger analizuje w kolejnych rozdziałach, pokazując, jak działalność artystyczna - „mityzacja rzeczywistości” - prowadzi ku reintegracji własnej osobowości, ku wyjściu z historycznych konfliktów i zadośćuczynieniu za doświadczoną degradację.

Powiązania mitu z masochizmem w jego różnych wymiarach opierają się na skomplikowanych logicznie wywodach sięgających do koncepcji psychologicznych, filozoficznych czy nawet religijnych i bywają zaskakujące, a czasem dyskusyjne. Ale chyba takie właśnie, konsekwentne, jednorodne i wielostronne spojrzenie na działalność literacką i plastyczną Schulza pozwala czytać ją jako spójny makrotekst kultury. Pod tym względem książka Augsburger jest przykładem znakomicie przeprowadzonej analizy komparatystycznej par excellence. Berlińska badaczka rozpatruje twórczość artysty z Drohobycza we wszystkich jej przejawach: włącza $\mathrm{w}$ swoje rozważania również jego listy, teksty publicystyczne, polemiki i recenzje, konfrontuje poglądy Schulza oraz współczesnych mu pisarzy (Debory Vogel, Witkacego, Gombrowicza), znajduje paralele z tekstami Leopolda von Sacher-Masocha, Tomasza Manna, filozofią Nietzschego, Bergsona. Wydobywa na światło dzienne tak mało znane konteksty, jak proza rosyjskiego symbolisty Andrieja Biełego czy pisma indologa Heinricha Zimmera. Sporo miejsca poświęca też dzisiejszej recepcji Schulza w Niemczech, omawiając film Benjamina Geisslera Odnaleźć obrazy (Bilder finden), poświęcony poszukiwaniom tzw. fresków Schulza w willi Landaua w Drohobyczu.

W pierwszej z czterech głównych części studium, zatytułowanej Między krytyka rzeczywistości a poszukiwaniem sensu w micie, autorka szki-

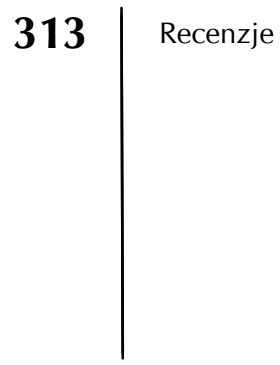


cuje biografię Schulza i epokę historyczną, w jakiej kształtowały się jego osobowość i dzieło. Omawia warunki społeczno-polityczno-etniczne w Galicji pierwszej połowy XX w., ze szczególnym uwzględnieniem sytuacji Żydów. Taki wstęp jest zrozumiały, gdyż adresatami książki są głównie czytelnicy niemieckojęzyczni, niekoniecznie obeznani ze spuścizną autora Sierpnia. Choć autobiograficzny charakter jego opowiadań i grafik nie ulega wątpliwości, to zdaniem Augsburger, wciąż kładzie się zbyt mały nacisk na tożsamość artysty uwarunkowaną historycznie: na fakt, że jego żydowskie korzenie i fakt wrośnięcia w kulturę polską nie połączyły się w monolityczną całość, ale zaskutkowały rozdarciem w osobowości pisarza (A 17). Obserwacja ta uświadamia, że hybrydyczność to niezwykle istotny rys indywidualności Schulza - cecha, której jego dzieło zawdzięcza swój uniwersalizm i trwałe miejsce w literaturze światowej i która powinna być należycie eksponowana. Niemiecka badaczka poszukuje w duchowym życiorysie artysty śladów doświadczeń kryzysu i zagrożenia, spowodowanych warunkami zewnętrznymi oraz przynależnością do grupy etnicznej skazanej albo na asymilację, albo na odizolowanie od reszty społeczeństwa. Augsburger przychyla się do przypuszczeń Sandauera i Ficowskiego, iż świadomość uczestnictwa w wydarzeniach przełomowych spowodowała u Schulza ucieczkę w sztukę, w mit, który daje nadzieję na ochronę własnej tożsamości przed rozbiciem.

Śledząc sposób, w jaki Schulz wycofuje się z zagrożeń realnego świata w mit, niemiecka badaczka przyjmuje dość nietypowy punkt wyjścia: nie tylko programowy esej Mityzacja rzeczywistości, ale także teksty Schulza tematyzujące mit historyczny na przykładzie legendy Piłsudskiego ${ }^{12}$. Próbę - jej zdaniem nieudaną - mityzacji bohatera dziejowego (polegającej na syntezie fragmentów: pojedynczych wydarzeń historycznych w całość o znaczeniu metafizycznym) Augsburger wiąże z filozofią Nietzschego, estetyką dionizyjską, a także rozważaniami Kierkegaarda o sprzeczności między racjonalną, ogólnoludzką etyką a jednostkową, absurdalną wiarą (A 45). Podatność Schulza na kult postaci historycznej Augsburger interpretuje jako sygnał predyspozycji masochistycznych: poszukiwanie „wielkiej osobowości”, której oddziaływaniu można się poddać bez reszty. Jednocześnie dowodzi, że Schulz - mimo zabiegów retorycznych - nie potrafi pokazać, na czym miałby polegać ogólnoludzki, metafizyczny sens mitu Piłsudskiego. Jak bowiem można wnioskować z innych wypowiedzi Schulza ${ }^{13}$, mityzacji może ulec tylko prywatne, jednostkowe doświadczenie, pozwalające na autoironiczny dystans wobec

12 Szkic Powstaja legendy oraz recenzje tomów Kazimierza Wierzyńskiego Wolność tragiczna i Juliusza Kadena-Bandrowskiego Pod Belwederem.

${ }^{13}$ Chodzi o napisane po niemiecku Exposé o „Sklepach cynamonowych”. 
własnej biografii, natomiast $\mathrm{w}$ przypadku zjawisk, postaci i wydarzeń „publicznych” próba ich mityzacji zawsze kończy się fiaskiem (A 53). Augsburger w skomplikowanym, erudycyjnym wywodzie ukazuje tu jeden $\mathrm{z}$ wielu paradoksów, jakimi naznaczony jest światopogląd Schulza - sygnał sprzeczności, rozłamów i niekonsekwencji w jego twórczym działaniu i osobowości, z których jednak wypływa siła estetycznego oddziaływania jego sztuki.

Kolejne, dygresyjne rozdziały części pierwszej traktują w porządku chronologicznym o pewnych epizodach i zagadnieniach z biografii Schulza, rzucających światło na jego twórczą indywidualność. Chodzi o współpracę translatorską z Józefiną Szelińską, plany związane z Mesjaszem, a także związki artystyczne z Deborą Vogel. Analiza Schulzowskiej recenzji tomu Akacje kwitna prowadzi do wniosku, że autor Sanatorium pod Klepsydra poprzez dementowanie podobieństw tematycznych między prozą własną a Vogel oraz krytykę fragmentów subiektywnych i emocjonalnych podświadomie broni własnej twórczości przed zarzutem masochizmu (A 68). Rozdział Po inwazji to szkic do portretu ostatniego „pracodawcy” Schulza, esesmana Feliksa Landaua; na podstawie jego dzienników Augsburger kreśli sylwetkę człowieka brutalnego i czułostkowego jednocześnie. Przypomina tezę Th. Adorna o tym, że system nazistowski wychowywał swoich zwolenników na ludzi podporządkowanych, zdolnych $\mathrm{z}$ pokorą znosić cierpienie; tak wyuczony masochizm łatwo przeradzał się w sadyzm. Augsburger przypuszcza, że Landau projektował na Schulza własną słabość charakteru, na którą pozwalał sobie wyłącznie w życiu prywatnym (A 91). Przypomnienie znanych okoliczności tragicznej śmierci autora Sanatorium pod Klepsydra nasuwa ponurą refleksję: jak pokazuje historia, masochizm jako predyspozycja psychiczna mógł równie dobrze zaowocować powstaniem wybitnych dzieł sztuki, jak i doprowadzić do dziejowej katastrofy.

Część druga książki (Między zdegradowana rzeczywistościa a degradacja własnego $\mathrm{Ja}$ ) ma w założeniu traktować o masochizmie jako fenomenie psychologicznym i kulturowym, obecnym w tekstach drohobyckiego pisarza. Jednak mimo deklarowanej perspektywy kulturoznawczej Augsburger w zasadzie skupia się na jednostkowym, psychologicznym wymiarze masochizmu. Omawia teksty publicystyczne (samego Schulza oraz pisane o nim) pokazujące, że współcześni wyraźnie dostrzegali pierwiastek masochistyczny $\mathrm{w}$ jego rysunkach i prozie. W przekonaniu niemieckiej badaczki Schulz celowo dążył do konfrontacji z recenzentami i komentatorami, aby wyartykułować interesującą go transcendentną strukturę i estetyczny wymiar masochizmu (A 99). W jego listach, autokomentarzach, a także wypowiedziach przytaczanych z drugiej ręki pojawiają się takie rysy, jak skłonność do narcyzmu, demonstracyjnej in- 
scenizacji własnego cierpienia oraz chęć wywyższenia i poniżenia obiektu seksualnego jednocześnie (A 114), co z punktu widzenia psychologii jest typowym mechanizmem masochistycznej reakcji emocjonalnej mężczyzny (upokorzenie masochisty idzie $\mathrm{w}$ parze z podświadomą próbą dowartościowania moralnego własnej osoby, aby usprawiedliwić pogardę odczuwaną wobec kobiety). Masochizm zatem to postawa ambiwalentna, naznaczona wewnętrznym rozdarciem, konfliktami i paradoksami psychologicznymi.

Artystyczne potwierdzenie tendencji masochistycznej, ujawnionej w publicystyce bądź też przypisywanej Schulzowi przez czytelników, autorka odnajduje w opowiadaniu Ulica Krokodyli z obecnym w nim wątkiem oscylacji między siłą zmysłowego przyciągania a intelektualną pogardą dla dzielnicy rozpasanej konsumpcji. Augsburger włącza w swoje odczytania tezy Sandauera o „zdegradowanej rzeczywistości” jako elemencie masochistycznym w twórczości Schulza, a także kabalistyczną interpretację Władysława Panasa. Rolą wyczekiwanego Mesjasza jest przywrócenie pierwotnego ładu i likwidacja pokosmogonicznego chaosu rozumianego jako moralny upadek, degradacja i upokorzenie ludzkości, co pozwala wiązać go z masochizmem. Natomiast przekonanie o „teleologicznym" masochizmie i rzekomym predestynowaniu pisarza do roli ofiary badaczka uważa za nieuprawnione. Wspólnym mianownikiem tych dwóch, jej zdaniem komplementarnych, interpretacji dzieł Schulza jest masochizm rozumiany jako relacja pan - poddany. Opiera się na niej zarówno odczytanie kabalistyczne (tęsknota za przemożną władzą Absolutu, za zbawieniem w sensie religijnym i transcendentnym), jak i koncepcja Sandauerowska, umożliwiająca wyeksponowanie i wyjaśnienie obecnych u Schulza konfliktów uwarunkowanych przemianami społeczno-historycznymi.

W dalszych rozdziałach Augsburger charakteryzuje „estetykę masochistyczną" w literaturze i sztukach plastycznych. I tu jednak nie tylko punktem wyjścia, ale i dominantą rozważań pozostają założenia psychologii. Autorka pokazuje, jak stosunek naukowców i opinii publicznej do masochizmu ewoluował na przestrzeni dziesięcioleci. O ile psychologia z przełomu wieków (S. Freud, R. Krafft-Ebing) uznawała męski masochizm za dewiację psychoseksualną o podłożu genetycznym, o tyle $\mathrm{w}$ latach czterdziestych XX w. dostrzeżono w nim zjawisko społeczno-kulturowe, nie zaś czysto biologiczne. Augsburger przywołuje psychologiczny portret masochisty nakreślony przez niemieckiego psychologa Theodora Reika. Masochista to despota zmuszający kobietę do zadawania bólu, ukryty narcyz, który znosi upokorzenie w nadziei na przyszły triumf moralny. Cechy masochistyczne wykazują wszyscy męczennicy, asceci i dobrowolne ofiary, rezygnujące $\mathrm{z}$ natychmiastowego uznania na

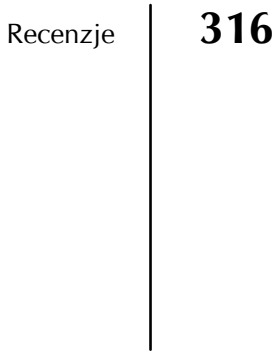


korzyść nagrody odsuniętej w czasie. Reik wyróżnia trzy cechy zachowań masochistycznych: potrzeba posiadania świadków i dążenie do inscenizacji własnego cierpienia; odsuwanie satysfakcji na przyszłość; intensywna praca wyobraźni antycypującej wynagrodzenie bólu. Właściwości te sprawiają, że masochizm szczególnie nadaje się do przedstawienia w sztukach wizualnych. Z kolei w literackich przedstawieniach tego tematu, których sztandarowym przykładem jest tekst Leopolda von Sacher-Masocha Wenus $w$ futrze (Venus im Pelz), dominuje technika napięcia, odsunięcia w czasie momentu seksualnego spełnienia; stosowane są takie chwyty, jak znieruchomienie akcji, zastygnięcie postaci w bezruchu - stąd częsta teatralizacja wydarzeń. Najważniejszym zmysłem jest dla masochisty wzrok, umożliwiający obserwację obiektu pożądania, często z ukrycia. Masochista i fetyszyzowana przezeń kobieta nie patrzą sobie $\mathrm{w}$ oczy ( $\mathrm{w}$ ujęciu psychoanalitycznym kobieta to dla masochisty obiekt niezaspokojonej tęsknoty, matka porzucająca dziecko - spuszczająca je z oczu, stąd odmowa nawiązania kontaktu wzrokowego). Dlatego masochizm oznacza też klęskę wzajemnego poznania i akceptacji obu płci. Wbrew tym ciekawym skądinąd obserwacjom nasuwa się myśl, że tak pojmowana estetyka sprowadza się głównie do pewnych wątków fabularnych, natomiast marginalizuje sprawy stylu, czyli języka.

Omawiając tekst Sacher-Masocha, Augsburger pokazuje konieczność analizy „estetyki masochistycznej” w kontekście refleksji kulturoznawczej i historycznej. W XIX w. wątek męskiego masochizmu - nieakceptowanego, uznanego za dewiację (w przeciwieństwie do masochizmu kobiecego, uważanego za „naturalny”) - rozwijał się w literaturze i sztuce niejako podskórnie, jako nieoficjalna reakcja na literackie wizje mieszczańskiego, patriarchalnego porządku społecznego. W masochistycznym „scenariuszu” mężczyzna projektował bowiem na kobietę własne obsesje i lęki, wypierane ze świadomości. W masochizmie można też upatrywać - wzorem Johna Noyesa - zjawiska historycznego, oznaki kryzysu mieszczańskiego społeczeństwa w monarchii austro-węgierskiej końca XIX w. Utwory literackie, takie jak teksty Sacher-Masocha, ukazują kontynuację przemocy społecznej na gruncie prywatnym. Stosunek upokarzanego mężczyzny i kobiety dręczycielki obrazuje walkę o władzę - zjawisko uniwersalne. Ból i przemoc należą do najbardziej podstawowych ludzkich doświadczeń, są koniecznością dziejową, dlatego masochizm można odczytywać jako próbę transformacji nieuniknionego cierpienia w źródło rozkoszy i satysfakcji.

Psychologiczna interpretacja masochizmu jako indywidualnej perwersji, połączona z jego rozumieniem społeczno-historycznym (specyficzny stosunek władzy, który mógł się wykształcić w warunkach wieloetnicznej społeczności Galicji), rzeczywiście daje możliwość ściślejszego niż 
dotąd powiązania prozy Schulza z jego grafikami. Jednak ten drugi, ponadjednostkowy aspekt masochizmu zostaje przez badaczkę jedynie zasygnalizowany. Augsburger przekonująco dowodzi, że masochizm ujawnia się $\mathrm{w}$ Xiędze bałwochwalczej w wymiarze zarówno prywatnym, psychologicznym (brak realnego, równoprawnego partnera w związku, klęska wzajemnej akceptacji), jak i egzystencjalnym (doświadczenie kryzysu). Natomiast brak konkretnych przykładów, które egzemplifikowałyby wyjście poza psychologię i filozofię w kierunku kulturowym i społecznym. Omawiając grafiki cyklu pod katem „estetyki masochistycznej”, niemiecka kulturoznawczyni podkreśla obecny w rysunkach ambiwalentny stosunek mężczyzny do kobiety: wiernopoddańczej miłości, religijnemu kultowi fetyszyzowanej bogini ${ }^{14}$ towarzyszy gniew $\mathrm{z}$ powodu wszechwładztwa i nieosiągalności kobiety; emocja ta zostaje ukarana deformacją męskiego ciała. Twarze kobiet są brzydkie, demonstracyjnie obojętne i pozbawione wyrazu, co Augsburger interpretuje jako projekcję moralnej kapitulacji mężczyzny (A 189).

Część trzecia, zatytułowana Między panmaskarada a substancja, stawia sobie za cel opis konfliktów wynikających z masochizmu, które można ująć jako dialektykę „utraty substancji” i „tęsknoty za substancją". Realizują się one w Schulzowskiej metaforyce teatru i karnawału. Należy tutaj m.in. figura pierrota, omówiona na przykładzie trzech grafik: Swięto wiosny, Exlibris Stanistawa Weingartena oraz jednej z kart tytułowych do Xięgi bałwochwalczej, ukazującej pierrota z lustrem. W postaci tej Augsburger widzi symbol wyobcowania artysty ze społeczeństwa, a także lęku przed zniszczeniem potencjału twórczego przez wybujałą kobiecość (A 209). Przekonująca jest obserwacja, że skoro grafiki Schulza odbijane były z matryc, a więc każdy rysunek miał swoje lustrzane odbicie, to każda $\mathrm{z}$ masochistycznych inscenizacji ma swój domyślny „negatyw”: wizję egzystencji niewyobcowanej, pragnienie akceptacji przez otoczenie, bliskości, kontaktu, symbiozy z drugą osobą.

Omawiając recepcję twórczości Schulza w dwudziestoleciu (w rozdziale Masochizm i uwarunkowanie jego formy jezykowej), Augsburger podkreśla, że już współcześni dostrzegli obrazowość i synestetyczność jego prozy - cechy pozwalające odnaleźć w tekstach Schulza estetykę masochistyczną. Obrazowość opowiadań autorka rozumie nie tyle jako jeden z wyróżników literackości, ile jako statyczność i „demonstracyjność” wydarzeń - sposób przedstawiania wspólny dla twórczości pla-

${ }^{14}$ Fetyszem w Xiędze bałwochwalczej jest np. stopa, fetyszyzowana nawet za sprawą techniki: stopa kobieca jest na ogół biała, nietknięta rylcem artysty przygotowującego matrycę, a więc pozostaje nietykalna nie tylko w znaczeniu przenośnym, ale i całkiem dosłownym (A 189). 
stycznej i prozatorskiej pisarza w stopniu nie mniejszym niż oczywiste zbieżności tematyczne.

Augsburger łączy masochizm również z dialektyką "substancji” i „panmaskarady”, dezintegracji i dążenia do mistycznej jedności. W prozie autora Xięgi bałwochwalczej owa jedność - którą badaczka wiąże z kategorią dionizyjskości - przejawia się w możliwości przemiany ludzi w rzeczy i zjawiska oraz odwrotnie, co ilustruje opowiadanie Wichura. Autorka dowodzi, że w centralnym motywie prozy Schulza - degradacji, zniszczeniu, „bankructwie realności” - również dochodzi do głosu zjawisko masochizmu. Mit i powrót do dzieciństwa stanowią pozorną ucieczkę przed zagrożeniem tożsamości w sensie psychologicznym, biologicznym, społecznym - co zdaniem autorki jest zjawiskiem paradoksalnym, ponieważ w psychoanalizie Freudowskiej wszelkie czynności powtarzające się, regresywne mają charakter (auto)destrukcyjny. Jednak w przypadku twórcy Sanatorium pod Klepsydra to właśnie rozkład, rozszczepienie osobowości, transgresja gwarantuje integralność własnego Ja. Schulz potrafi zatem pokazać twórczy potencjał czynności i stanów ocenianych w psychologii negatywnie. Ten kolejny paradoks - rozmycie granic własnej osoby jako warunek przyszłej jedności - Augsburger odczytuje jako wizję masochistyczna powracającą we wszystkich tekstach literackich i plastycznych Schulza. W zdegradowanych, poniżonych, zdeformowanych postaciach opowiadan (takich jak: manekiny, pałuby, figury panoptikum) można się dopatrzeć sobowtórów masochisty; reprezentują one zjawisko rozpadu i braku akceptacji przez otoczenie, a jednocześnie wskazują masochiście możliwość zrehabilitowania się i dowartościowania poprzez pisanie i wyrażoną w nim miłość własna (A 227).

Czwarta i ostatnia część: Tendencje do dezintegracji: motywy prozy Schulza $i$ ich tto jest chyba najlepsza, a w każdym razie może być dla literaturoznawcy źródłem szczególnej satysfakcji poznawczej. Autorka omawia pod kątem psychoanalitycznym trzy teksty Schulza: Sanatorium pod Klepsydra, Traktat o manekinach oraz Księgę, śledząc w nich oznaki „regresywnych i utopijnych tendencji do dezintegracji” (A 234). Symptomy te w pierwszym opowiadaniu można dostrzec na poziomie kształtowania czasoprzestrzeni: w zabiegu mityzacji czasu. Zburzenie chronologicznego porządku wydarzeń, rozbicie jedności czasu byłoby narracyjną paralelą postawy masochistycznej w sensie psychicznej autodestrukcji. Uzasadnieniem dla psychoanalitycznej, freudowskiej lektury opowiadania Sanatorium pod Klepsydra jest stosowana przez Schulza konwencja marzenia sennego, a także pojawiające się elementy niesamowitości w rozumieniu Freuda, takie jak: rozszczepienie Ja, ciągłe powroty i powtórzenia tych samych wątków, zachowań, scenerii itp. Augsburger wskazuje na ambiwalentny stosunek bohatera tekstu do Ojca: obraz cho- 
rego, zaniedbanego pacjenta wyzwala w Józefie instynkt opiekuńczy, ale też poczucie bezsilności i winy; z kolei wizja Ojca jako aktywnego człowieka interesu (należąca do sfery marzenia sennego) wzbudza poczucie niższości. Bohater oscyluje między dwiema postawami typowymi dla masochisty: pragnieniem dominacji i dążeniem do władzy (projektowanym na drugą osobę) a chęcią podporządkowania się i kontemplacją własnej niemocy. Motyw masochizmu powraca w opowiadaniu również na płaszczyźnie relacji kobieta - mężczyzna. Świadczą o tym pozornie mało znaczące epizody, takie jak spotkanie z pokojówką, unikającą wzroku bohatera, czy scena, w której Józef podgląda dziewczynę z dużej odległości przez „refraktor astronomiczny”. Takie zachowania wskazują na niemożność nawiązania przez mężczyznę bezpośredniego kontaktu z kobietą - rys typowy dla relacji masochistycznej, dokładnie omówiony w rozdziale o autorskich ilustracjach do opowiadania Sanatorium pod Klepsydra ${ }^{15}$.

Błyskotliwa, ale i dyskusyjna jest próba interpretacji opowiadania Księga w kontekście grafik z Xięgi bałwochwalczej. Augsburger uważa opowiadanie za pretekst do wyrażenia nieopisywalnego doświadczenia utraty (Księgi, czyli symbolu wszelkich form bytu), rekompensowanego własnym aktem twórczym, podnoszącym szpargał do rangi Autentyku. Narrator - artysta, geniusz - utożsamiony zostaje z masochistą, który staje się świadkiem profanacji Księgi, używanej jako papier śniadaniowy. Sytuacja ta koresponduje z pogardą dla poezji, jaką okazują kobiety w Xiędze bałwochwalczej. Również znana metafora „ułamków zwierciadła”, wskazujących na większą całość, na „genialną epokę", wiąże opowiadanie Ksiegga z cyklem grafik: w masochistycznej „matrycy” przenośnia ta oznacza niemożność samopoznania w komunikacji z innymi ludźmi. Interpretację tę potwierdza refleksja narratora, że jego wspomnienia Autentyku pochodzą z czasów, kiedy „matki jeszcze nie było” (masochista to człowiek odrzucony w dzieciństwie przez matkę).

Wątpliwości może budzić opis ilustracji do opowiadania Księga, w których uwagę niemieckiej badaczki przykuwa postać kataryniarza

15 Augsburger zakłada, że omawiane rysunki dotyczą tylko tego jednego opowiadania - tak jak podaje np. katalog Bruno Schulz: Das graphische Werk z wystawy w Monachium i Berlinie z roku 1992 (przedruk w wydawnictwie dtv z roku 2000). Według innych źródeł ilustracje reprodukowane przez Augsburger na s. 338 i 340 (il. 8 i 10) odnoszą się do opowiadania Wiosna (zob. B. Schulz, Xięga bałwochwalcza, przygotował do druku i słowem wstępnym opatrzył J. Ficowski, Warszawa 1988, s. 49, 51). Niezgodność ta wcale nie umniejsza trafności spostrzeżeń badaczki i celności jej interpretacji. W gruncie rzeczy bowiem okazuje się bez znaczenia, do jakiego konkretnie tekstu prozatorskiego przyporządkuje się daną ilustrację. Dzieło plastyczne Schulza ma charakter totalny, jest to jeden „makrotekst”, a rysunki ilustrujące poszczególne motywy fabularne nie muszą formalnie wiązać się z danym tekstem. 
(il. 13 i 14 na s. 342-343). Motyw kalekiego grajka - przedstawiciela sztuki zredukowanej do automatyzmu - miałby wiązać Księge z grafikami z Xięgi bałwochwalczej (choć omawiane rysunki nie należą do tego cyklu). Zdaniem Augsburger, kataryniarz na obu szkicach adoruje stojącą na balkonie kobietę w typie macierzyńskim, która unika jego wzroku. Badaczka dopuszcza się tu chyba jednak pewnej nadinterpretacji, ponieważ nawet na dobrych technicznie reprodukcjach trudno stwierdzić, na kogo spogląda naszkicowana przez Schulza postać. Mimo to można chyba się zgodzić, że rysunki z kataryniarzem jako ilustracje do Księgi przedstawiają to, czego zabrakło w Xiędze bałwochwalczej: tęsknotę za miłością macierzyńską ${ }^{16}$, zaś postawa masochistyczna oznacza nie tylko erotyczną perwersję, ale też osamotnienie, wyobcowanie, chłód w stosunkach międzyludzkich. Niewątpliwie też opowiadanie Księga tematyzuje różnorodne doświadczenia bólu, kryzysu egzystencjalnego, rozpadu tożsamości, przemocy społecznej, dehumanizacji współczesnej kultury.

W rozdziale Masochistyczne? Przesunięcie potrzeby transcendencji $w$ ezoteryke pojęcie masochizmu uzupełnione zostaje o wymiar religijny i ezoteryczny. W epoce, na którą przypadł życiorys Schulza, historyczne przemiany i wstrząsy wzmogły lęki i wątpliwości egzystencjalne towarzyszące ludzkości od zawsze i skłoniły do tego, by ich ukojenia szukać w źródłach innych niż dotychczas: w gnozie, ezoteryce, filozofii Wschodu. W ujęciu Ericha Fromma ucieczka od jednego z najistotniejszych lęków, jakim jest obawa przed śmiercią, prowadzi albo ku materializmowi, albo ku religii. Religia - poddanie się „wyższej” władzy - miałaby charakter masochistyczny, masochizm zaś byłby jej zsekularyzowaną postacią.

Teza Fromma przełożona na obszar sztuki prowadzi autorkę książki do konstatacji, że artystyczną konsekwencją egzystencjalnych poszukiwań czasów Schulza może być albo „poetologiczny nihilizm”, albo religijność. Jednak teksty Schulza nie mają nic wspólnego z nihilizmem: przeczą temu motywy transcendencji, mitu, substancji i panmaskarady (A 291), pozwalające przypisać jego dorobek raczej do symbolizmu. Niemiecka badaczka stawia więc pytanie, czy w epoce kryzysu i katastrof możliwa jest jakaś trzecia droga do pokonania lęku przed śmiercią - rozwiązanie konkurencyjne wobec alternatywy Fromma, a więc niesprowadzające się ani do materializmu, ani do religii. W świetle poprzedzających rozważań $\mathrm{i}$ analiz jest to pytanie retoryczne: takim rozwią-

16 Porównując ideał kobiety w grafikach Schulza i prozie Sacher-Masocha, Augsburger zwraca uwagę na istotną różnicę: podczas gdy u autora Wenus $w$ futrze kobieta to hetera i sadystka, ale też opiekuńcza matka, typ symbiotyczno-dominujący, to u Schulza tego ostatniego wyobrażenia brak zupełnie (A 198).

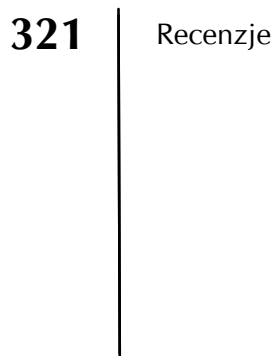


zaniem okazuje się „masochistyczna sztuka”, która - przynajmniej dla artysty - stanowi akt wyzwolenia.

Ostatni tekst ilustrujący tezy autorki to Traktat o manekinach ${ }^{17}$ $\mathrm{z}$ centralnym problemem aktu twórczego, który u Schulza przybiera postać sadyzmu - gwałtu zadanego materii. Jakub artysta nosi cechy masochisty i sadysty równocześnie: w wyimaginowanych czynnościach kreacji mści się za doznane upokorzenia i brak uznania, niszcząc i wchłaniając w siebie pierwiastek kobiecy - istotę, która odmówiła mu akceptacji. Wszechmocy artysty towarzyszy jednak bezsilność, kompensowana w sferze fantazji. O ile demiurgiczne zapędy Jakuba odczytywane bywają jako obrona przed śmiercią, zbawienie samego siebie, o tyle Augsburger widzi w nich raczej zintegrowanie z poezją autodestrukcyjnych dążeń, których źródłem jest popęd śmierci (A 309).

W ostatnim rozdziale badaczka dokonuje próby interpretacji Schulzowskiego hasła „Mniej treści, więcej formy!”, przywołując jego konteksty teoretycznoliterackie: rosyjski formalizm, zaumnyj jazyk rosyjskich futurystów, koncepcje awangardy krakowskiej, wreszcie teorię Czystej Formy Witkacego, zestawioną z filozoficznym przesłaniem Schulza. Jak pisze Augsburger, metafizyczny egzystencjalizm Witkacego dopuszcza perspektywy paradoksalne: banalność i wzniosłość, skończoność i nieskończoność, jedność i rozproszenie, przypadkowość i nieuchronność ponieważ filozofia ta opiera się na przekonaniu, że w głębi rzeczy musi istnieć jakaś istotna jedność. Taką właśnie ,jedność w sprzecznościach” sygnalizuje w swej twórczości plastycznej i literackiej Schulz (A 310). Wyraża się ona także w konflikcie między groteską uprawianą przezeń $\mathrm{w}$ praktyce a teorią poszukującą integralności i sensu.

Podsumowując, omawiane studium należy ocenić jako znaczący wkład do najnowszych badań nad spuścizną Schulza. Zebrano tu chyba wszystkie konteksty interpretacyjne i sposoby odczytań, jakie zaproponowano do tej pory ${ }^{18}$. Argumentacja berlińskiej kulturoznawczyni, choć niekiedy nazbyt zawiła, przynosi wiele oryginalnych, nowatorskich i ważkich spostrzeżeń. Niezależnie od swych niezaprzeczalnych walorów książka prowokuje też do pewnych pytań i wątpliwości.

Można się zastanawiać, czy biograficzne podejście do twórczości artysty nie jest anachronizmem - nawet jeśli wziąć pod uwagę, że mono-

17 Tytuł ten w omawianej pracy obejmuje wszystkie cztery opowiadania z cyklu o manekinach.

18 Wobec mnogości nazwisk, przywoływanych wielokrotnie w różnych miejscach, zdecydowanym mankamentem książki jest brak indeksu osobowego. Dyskomfort polskojęzycznego czytelnika mogą też budzić dość liczne błędy literowe w nazwiskach i nazwach polskich, tytułach utworów itd., co jest skądinąd zrozumiałą konsekwencją wydania pracy przez wydawnictwo niemieckie. 
grafia o orientacji kulturoznawczej z góry zakłada konieczność włączenia w obszar analizy czynników socjologicznych czy historycznych. Augsburger słusznie uważa, że tak nie jest: właśnie dlatego, że pewne zjawiska w twórczości Schulza przestają być jego prywatną, mało znaczącą obsesją czy osobliwością tematyczną, a stają się interpretacyjnym kluczem, gdy powiązać je z tłem społecznym i epoką kształtującą artystę i jego współczesnych. Kłopot w tym, że poszerzenie kategorii masochizmu o kwestie społeczne pozostaje raczej w sferze postulatów, a przynajmniej wymagałoby pewnych dopowiedzeń. W dyskusji o grafikach i opowiadaniach Schulza masochizm jawi się głównie jako sprawa jednostkowa, psychologiczna - może dlatego, że zaprezentowane interpretacje psychoanalityczne są najbardziej udane i przekonujące. Tymczasem właśnie przykład Xięgi bałwochwalczej byłby okazją do „otwarcia” analizy w stronę socjologii. Warto bowiem zauważyć, że nasycenie twórczości Schulza wątkami masochistycznymi nie jest wszędzie takie samo. Podczas gdy motywy masochistyczne w dziełach udostępnianych szerokiej publiczności wyrażane są dyskretnie i aluzyjnie, to w sposób wyraźny, demonstracyjny pojawiają się tylko w Xiędze bałwochwalczej, kolportowanej prywatnie, w niewielu egzemplarzach. Ten rodzaj autocenzury, polegający na wykluczeniu twórczości jawnie masochistycznej z oficjalnego obiegu, wynikał $\mathrm{z}$ negatywnej oceny samego zjawiska w odbiorze społecznym. Zatem kwestia wstydliwości masochizmu, kamuflowania jego artystycznych przejawów pod wpływem przymusu zewnętrznego to już fenomen nie tyle psychologiczny, ile obyczajowy i kulturowy.

Książka Augsburger wyraźnie pokazuje, że w dzisiejszym dyskursie literaturoznawczym uruchamiane są całkiem nowe kategorie. W przypadku omawianej monografii są to narzędzia badawcze psychologii i psychoanalizy, w przypadku prac spod znaku postkolonializmu - zagadnienia społeczne. Wszystkie te kategorie istnieją niejako „obok” języka. Wypada zatem stwierdzić, że praca berlińskiej autorki jest wyrazem, a może dopiero zapowiedzią nowych dążeń nie tylko w badaniach nad samym Schulzem, ale i w humanistyce czasów najnowszych. Daje przy$\mathrm{kład}$, że literaturą mogą $\mathrm{z}$ powodzeniem zajmować się przedstawiciele dyscyplin ościennych - badacze „Z zewnątrz”, którym udaje się naświetlić zjawiska niedostrzegane przez literaturoznawców.

Katarzyna Lukas 